\title{
Tracing the Cadomian magmatism with detrital/inherited zircon ages by in-situ U-Pb SHRIMP geochronology (Ossa-Morena Zone, SW Iberian Massif)
}

\author{
M.F. Pereira ${ }^{\text {a,* }}$, M. Chichorro ${ }^{\text {}}$, A.R. Solá c, J.B. Silva ${ }^{\text {d }}$, T. Sánchez-García e , F. Bellido ${ }^{\text {e }}$ \\ a IDL, Departamento de Geociências, Universidade de Évora, Portugal \\ b CICEGe, Departamento de Ciências da Terra, Universidade Nova de Lisboa, Portugal \\ c LNEG, Unidade de Geologia e Cartografia Geológica, Portugal \\ d IDL, Departamento de Geologia, Universidade de Lisboa, Portugal \\ e IGME, Spain
}

\section{A R T I C L E I N F O}

\section{Article history:}

Received 27 April 2010

Accepted 20 November 2010

Available online 28 November 2010

\section{Keywords}

Detrital/inherited zircon ages

Cadomian magmatic arc

Ediacaran

Cambrian

Northern Gondwana margin

\begin{abstract}
A B S T R A C T
U-Pb SHRIMP geochronology on zircon extracted from a granite, a sandstone and a quartzite of the SW Iberian Massif (Ossa-Morena Zone), was used in order to investigate the contribution of Late Neoproterozoic (Cadomian) tectonothermal history to the crustal growth of northern Gondwana. The analysed Cambrian rocks were sampled along the southern margin of the Coimbra-Cordoba shear zone (Barquete granite and Crato sandstone), and within this shear zone (Ouguela quartzite). The Barquete granite yielded a crystallization age of $526 \pm 4 \mathrm{Ma}$ and evidence for Neoproterozoic and Paleoproterozoic inherited ages. The geochemical signature of the Barquete granite matches the igneous activity of the initial magmatic flooding of the Ossa-Morena Zone during the Early Cambrian. The petrography and geochemical signature of the Crato and Ouguela sandstones indicate that these clastic rocks were mainly derived from felsic igneous rocks. The youngest detrital zircon grain extracted from the Crato sandstone, dated at $552.7 \pm 5.5 \mathrm{Ma}$, has a zircon overgrowth that yielded $532 \pm 5.6 \mathrm{Ma}$. In the Ouguela quartzite, the youngest concordant age yielded $556.4 \pm 5.7 \mathrm{Ma}$, but we also found a zircon overgrowth dated at $536.2 \pm 5.6 \mathrm{Ma}$. The ages of the youngest detrital zircon in each sedimentary rock place an upper limit on the deposition age of Early Cambrian (c. 536$532 \mathrm{Ma}$ ). Four main Late Neoproterozoic age clusters at c. 640-638 Ma, c. 612-613 Ma, c. 590-585 Ma and c. $560 \mathrm{Ma}$ were recognized in the populations of detrital zircons from both sandstones. These ages of zirconforming events seem to represent four successive thermal/magmatic pulses that overlap the Cadomian and Pan-African orogenies. These findings match other results published for the OMZ. Our U-Pb results show that detrital zircons in siliciclastic sediments and inherited zircon in granites are dominated by Neoproterozoic ages and few Paleoproterozoic and Archean ages. Those ages reported in the Ossa-Morena Zone rocks, together with a remarkable lack of Mesoproterozoic ages suggest that the clastic rocks in this peri-Gondwana basin were derived from the West African craton. The large population of Late Cryogenian and Ediacaran ages indicates denudation of the Cadomian basement during the Early Cambrian. A potential source for the detrital and inherited zircons found in this study is a long-lived magmatic arc that is only partly exposed in the SW Iberian Massif but is well represented in other peri-Gondwana regions. The large amount of Cadomian ages obtained in this study (c. 640-560 Ma) reinforces the idea that Cadomian magmatism played a significant role in the continental crustal growth history of Late Neoproterozoic uplift and erosion in Western and Central Europe (Cadomia).
\end{abstract}

(C) 2010 Elsevier B.V. All rights reserved.

\section{Introduction}

The Neoproterozoic is a well documented time of enhanced crustal growth, with a lot of juvenile crust development. Late Neoproterozoic crustal evolution was profoundly influenced by "Pan-African" (c. 650$550 \mathrm{Ma}$ ) collisional events that resulted in the formation of Gondwana

\footnotetext{
* Corresponding author.

E-mail address: mpereira@uevora.pt (M.F. Pereira).
}

(e.g. Dalziel, 1997; Powell et al., 1993) and subduction along the northern periphery of Gondwana in response to those collisions (Murphy et al., 2002). Nowadays, dispersed by the influence of ancient Variscan-Appalachian and modern Alpine-Himalaya displacements these inliers of a Late Neoproterozoic orogeny probably formed a thousand-kilometre continuous Cadomian-Avalonian belt along the northern Gondwana margin (Bozkurt et al., 2008; Murphy et al., 2002; Murphy and Nance, 1991; Nance and Murphy, 1994; Nance et al., 2008, 2010). The Ossa-Morena Zone (OMZ) located in the SW Iberian Massif, the North Armorican Cadomian Belt (Armorican 